Pleione 12(1): 105 - 109. 2018.

ISSN: 0973-9467

(C) East Himalayan Society for Spermatophyte Taxonomy

doi:10.26679/Pleione.12.1.2018.105-109

\title{
Rediscovery of Sterculia striatiflora Mast. (Malvaceae) and its new record for the flora of India
}

\author{
Dipankar Borah and A. P. Das \\ Department of Botany, Rajiv Gandhi University, Rono Hills, Doimukh 791112, Arunachal Pradesh, India \\ E-mails: dipankarborah085@gmail.com; apdas.nbu@gmail.com
}

[Received 12.05.2016; Revised \& accepted 18.05.2018; Published 30.06.2018]

\begin{abstract}
One rare, poorly known species Sterculia striatiflora Mast. (Sterculiaceae/ Malvaceae) is recently recorded from the Arunachal Pradesh of India representing a new record to the flora of the country. The plant shares similarity with its closely related species viz. S. hamiltonii (Kuntze) Adelb. - a small tree or shrub found in N.E India, with its shrubby habit and flower structure, whereas differs from it in the plant height, panicle length and structure of perianth lobes. Detailed information are provided here for its identification.
\end{abstract}

Key words: Flora of India, Sterculia striatiflora, rediscovery, new record, Malvaceae/ Sterculiaceae

\section{INTRODUCTION}

The conventional family Sterculiaceae (Bentham \& Hooker 1862 - 1883; Cronquist 1988), consisting of some 70 genera and 1500 species, is a large taxon of tropical and subtropical regions (Cronquist 1988; Mabberly 2008). The family is represented by 68 species covering 19 genera in India (Malick 1993) and it enjoys mostly the tropical and subtropical distribution and occasionally extending to the temperate regions of the world (Mitra et al. 2015). The genus Sterculia L. is circumscribed by around 200 species worldwide (Mabberly 2008). Materials for the Flora of Arunachal Pradesh (Hajra et al. 1996) recorded 9 species of this genus for the state. And, Kanjilal et al. (1934) recorded 8 species from the greater Assam comprising of Arunachal Pradesh and other Northeastern states. Masters (1874) recorded 31 species in The Flora of British India of which only two are shrubby under the Section Eusterculia, namely $S$. striatiflora Mast. and S. linguifolia Mast. Of these, S. striatiflora was described from Kachin of Myanmar (Burma), and S. linguifolia from Tavoy (Myanmar) of the earlier greater British India.

During the last week of February (2018) on a field visit to Pashighat region of Siang District of Arunachal Pradesh (India), the authors have spotted good population of a shrubby species of Sterculia L. (Malvaceae) in the floor of Jonai Reserve Forest. Little later, in the first week of April (2018) again it was collected from Jampa forest in Papum Pare District of the same state. Later on, on perusal of literature it was found to be S. striatiflora Mast. and is matching nicely with the Kew Herbarium image no. K000671639 (collected from Myanmar on 29.03.1837). From the extensive literature and herbarium survey it is now realized that the species was not earlier collected from India.

Though the name Sterculia striatiflora Mast. is recorded as a 'unresolved' taxa in www.theplantlist.org, it is, however, recorded as an accepted name in http:// 

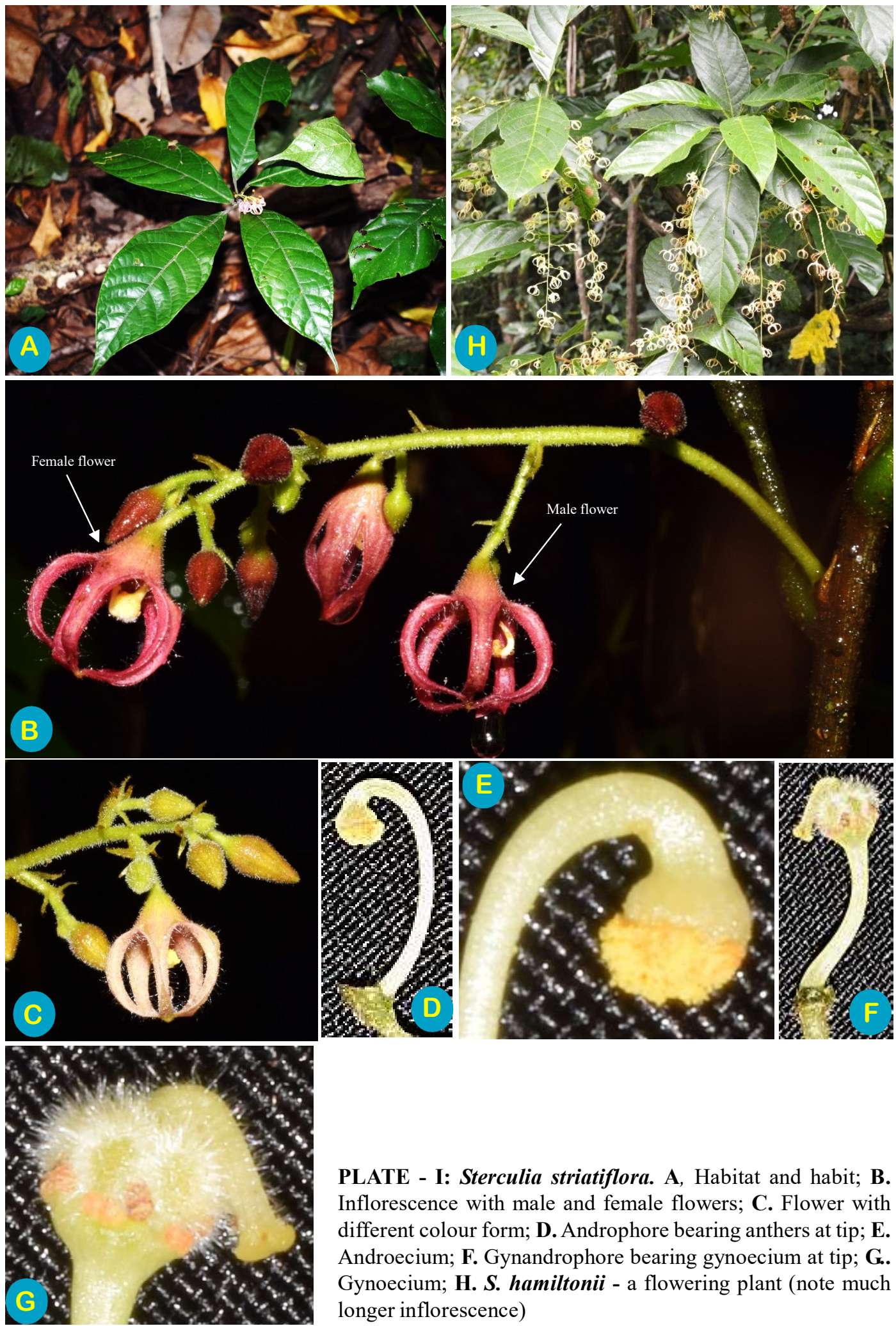

PLATE - I: Sterculia striatiflora. A, Habitat and habit; B. Inflorescence with male and female flowers; C. Flower with different colour form; D. Androphore bearing anthers at tip; E. Androecium; F. Gynandrophore bearing gynoecium at tip; G. Gynoecium; H. S. hamiltonii - a flowering plant (note much longer inflorescence) 
powo.science.kew.org/taxon/urn:lsid:ipni.org:names:825479-1. From our literature survey and morphological studies we also reached to the conclusion that $S$. striatiflora is one distinct species. The herbarium and literature records show that, so far, the species was endemic to Myanmar region only [http:/www.botanicus.org/primeocr/mbgserv14/botanicus3/b12950567/ 39088011697034/39088011697034_0388.txt]. So, the present collection of the species from two localities in Arunachal Pradesh expressed its extended distribution in India. However, in CAL or ASSAM herbaria there is no specimen of this species. The last known collection of the plant was well over a century back so it also the re-discovery of the species.

\section{TAXONOMIC TREATMENT}

Sterculia striatiflora Mast. in Hook.f., Fl. Brit. India 1: 356. 1874. [Malvaceae/ Sterculiaceae] [PLATE - I]

\section{Type: K000671639 (K) from Kachin, Myanmar (Burma!)}

Shrubs, $1-1.5 \mathrm{~m}$ high, bark greenish grey. Leaves $15-25 \mathrm{~cm} \times 5-8 \mathrm{~cm}$, simple; lamina elliptic to oblanceolate, entire sometimes slightly undulate, caudate-acuminate, base cuneate, papery, only sparsely stellate-hairy above and thinly below mainly on nerves; Petioles $2-3.5 \mathrm{~cm}$, thickened just below the lamina; pulvinous terete; Stipules free lateral, narrowly subulate-acuminate, $4.5-6 \times 1.0-1.2 \mathrm{~mm}$, green, turns brown with age, herbaceous, stellate-hairy. Panicles axillary, $7-10 \mathrm{~cm}$, males and females flowers on same inflorescence, lax, drooping, branches capillary; Pedicels short, $3-5$ $\times 0.8-1 \mathrm{~mm}$ long, capillary; Bracts subulate, $3-3.5 \times 1-1.5 \mathrm{~mm}$, light green, persistent; peduncle, rachis, petiole and bracts densely hairy. Flowers dioecious, drooping, $8-10$

Table 1. Important differences between Sterculia hamiltonii and S. striatiflora.

\begin{tabular}{|c|c|c|}
\hline Characters & $\begin{array}{l}\text { S. hamiltonii [Masters 1874; e- } \\
\text { flora India] }\end{array}$ & $\begin{array}{l}\text { S. striatiflora [Masters } 1874 \& \\
\text { Present work] }\end{array}$ \\
\hline Habit & Shrubs to Small trees & Shrubs \\
\hline Lamina & $\begin{array}{l}10-33 \times 5-15 \mathrm{~cm} \text { long, } \\
\text { glabrous above, stellate and } \\
\text { simple minute adpressed hairs } \\
\text { beneath }\end{array}$ & $\begin{array}{l}15-25 \mathrm{~cm} \times 5-8 \mathrm{~cm} \text { long, } \\
\text { sparsely stellate-hairy above and } \\
\text { thinly below mainly on nerves }\end{array}$ \\
\hline Petioles & $\begin{array}{l}\text { Thickened and slightly geniculate } \\
\text { at tip, } 7-12(-20) \mathrm{cm} \text { long }\end{array}$ & $2-3.5 \mathrm{~cm}$ \\
\hline Stipules & $\begin{array}{l}40-50 \mathrm{~mm} \text { long, rusty } \\
\text { pubescent, caduceus }\end{array}$ & $\begin{array}{l}4.5-6 \times 1.0-1.2 \mathrm{~mm} \text {, free } \\
\text { lateral, green turning brown with } \\
\text { age, stellate hairy, persistent } \\
\text { herbaceous }\end{array}$ \\
\hline Panicles & $\begin{array}{l}\text { Axillary, rarely supra-axillary, } \\
\text { generally long peduncled, } 10-20 \\
\text { cm long }\end{array}$ & $\begin{array}{l}\text { Axillary, short peduncled, } 7-10 \\
\text { cm long }\end{array}$ \\
\hline Flowers & Pale to deep salmon coloured & $\begin{array}{l}\text { Pale yellow turning gradually to } \\
\text { dark pink to salmon }\end{array}$ \\
\hline Flower diameter & $20-25 \mathrm{~mm}$ & $8-10 \mathrm{~mm}$ \\
\hline Calyx tube & ca $3 \mathrm{~mm}$ long & $4-5 \mathrm{~mm}$ long \\
\hline Calyx lobes & $\begin{array}{l}1.2-1.5 \mathrm{~cm} \text { long, deltoid with } \\
\text { margins incurved }\end{array}$ & $\begin{array}{l}1.0-1.3 \mathrm{~cm} \text { long, lanceolate with } \\
\text { margins reflexed outward }\end{array}$ \\
\hline
\end{tabular}


108 Sterculia striatiflora - a new record for flora of India

$\mathrm{mm}$ in diameter; calyx petaloid, pale yellow to dark pink, greenish towards the base, colour becomes darker with age after blooming, tube $4-5 \mathrm{~mm}$, infundibuliform, lobes 5 , lanceolate with margins reflexed outward, joining together at the tips, $10-13 \mathrm{~mm}$ long, both surfaces densely villous, free on over matured flowers after the release of pollen grains; Male flowers: staminal column 9.8-10 mm long, curved downwards, glabrous; anther lobes 5, somewhat triangular, yellow, dehiscing longitudinally; pollens yellow, granular; Female flowers: gynandrophore $6 \mathrm{~mm}$ long, broadened towards the tip and 5lobed, each bearing one sterile anther; ovary $2 \mathrm{~mm}$ long, densely villous, hemispherical with 5 lobes; style $2.5 \mathrm{~mm}$ long, curved downward, greenish-white; stigma 5-lobed. Fruits not seen.

Flowering: February - April

Studied specimens: India, Arunachal Pradesh, East Siang District, Jonai Reserve Forests, $D$. Borah \& AP. Das 0206, dated 28.02.2018; Papum Pare District, Jampa Forest, D.Borah \& AP. Das 0254, dated 05.04.2018. [CAL, ASSAM, HAU]

Distribution: India (Arunachal Pradesh), Myanmar.

Habitat: Sterculia striatiflora was found in the moist tropical plains forests of Pasighat in East Siang District and in hilly but tropical regions of Papum Pare District of Arunachal Pradesh

Note: The plant shares similarity with its closely related species $S$. hamiltonii (Kuntze) Adelb. - a small tree or shrub found in N.E. India, with its shrubby habit and flower structure, whereas differs from it in the plant height, panicle length and structure of perianth lobes. Detailed information are provided here for its identification. Some important differences between these two species are presented in Table 1 to assist their easy recognition.

\section{Acknowledgements}

Authors are thankful to Dr. Samiran Pandey of Central National Herbarium (CAL), Botanical survey of India, for his assistance in procuring some information on herbarium and literature. They are also thankful to Mr. Oyem Dai of Pashighat for the alround support he extended to us during the field work. Data related to specimens and nomenclature were consulted with the permission of the Trustees of the Royal Botanic Gardens, Kew.

\section{LITERATURE CITED}

Bentham, G. \& Hooker, J.D. 1862 - 1883. Genera Plantarum. 3-vols. L. Reeve \& Co Ltd, Ashford, Kent. London.

Cronquist, A. 1988. Evolution and Classification of Flowering Plants. $2^{\text {nd }}$ edn., New York Botanical Garden, Bronx, New York.

Mabberley, D.J. 2008. Mabberley's Plant Book, a portable dictionary of plants, their classification and uses. Cambridge University Press, Cambridge.

Malick, K.C. 1993. Sterculiaceae. In: Sharma, B.D. \& Sanjappa, M. (eds.), Flora of India. Vol. 3. Botanical Survey of India, Calcutta. Pp. $407-476$.

Mitra S.; Maiti, G.G. \& Maity, D. 2015. Structure and distribution of heteromorphic stomata in Pterygota alata (Roxb.) R. Br. (Malvaceae, formerly Sterculiaceae). Adansonia, sér. 3, 37(1): 139 - 147.

Hajra, P.K.; Verma, D.M. \& Giri, G.S. (eds.) 1996. Materials for the Flora of Arunachal Pradesh, Vol. I. Flora of India ser. 2, Botanical Survey of India, Calcutta. 
Kanjilal, U.N.; Kanjilal, P.C; Das. A. \& Purkaystha, C. 1934. Flora of Assam, Vol. 1, Assam Govt. Press, Shillong.

Masters, M.T. 1874. Sterculiaceae. In: Hooker, J.D., The Flora of British India. Vol. 1. L. Reeve \& Co. Ltd., England. pp. 353 - 379.

http://www.botanicus.org/primeocr/mbgserv14/botanicus3/b12950567/39088011697034/ 39088011697034_0388.txt [Check list of the plants of Myanmar]

http://powo.science.kew.org/taxon/urn:1sid:ipni.org:names:825479-1

www.theplantlist.org 